\title{
Refractory Aggressive Non-Hodgkin Lymphoma
}

National Cancer Institute

\section{Source}

National Cancer Institute. Refractory Aggressive Non-Hodgkin Lymphoma. NCI

Thesaurus. Code C156233.

An aggressive non-Hodgkin lymphoma that is resistant to treatment. 